\title{
Studies toward the identification of transcription factors in cassava storage root
}

\author{
Cláudia Regina Batista de Souza ${ }^{1,2^{*}}$, Elionor Rita Pereira de Almeida ${ }^{1}$, Luiz Joaquim Castelo Branco Carvalho' and $^{2}$ \\ Eugen Silvano Gander ${ }^{1}$
}

\begin{abstract}
${ }^{1}$ EMBRAPA - Recursos Genéticos e Biotecnologia, Parque Estação Biológica-PqEB, CP 02372, CEP 70770-900, Brasília, DF, Brasil; ${ }^{2}$ Current Address: Departamento de Genética, Centro de Ciências Biológicas, Universidade Federal do Pará, Rua Augusto Corrêa n. 01, Guamá, CEP 66075-110, Belém, PA, Brasil; *Corresponding author: bsouza@ufpa.br
\end{abstract}

Received: 29/09/2003, Accepted: 06/11/2003

Transcription factors play important roles in several physiological processes. In recent years many transcription factors have been isolated from plants and they are emerging as powerful tools in the manipulation of plant traits. In this work we initiated studies in order to isolate transcription factors from cassava (Manihot esculenta Crantz), an important tropical and subtropical crop. Our results show three kinds of proteins expressed differentially in cassava storage root and immunologically related to the opaque-2 transcription factor from maize. Southwestern experiments showed two proteins capable of interacting in vitro with the DNA sequence of the be2S1 gene from the Brazil nut tree.

Key words: bZIP, cis-acting elements, expression, gene regulation, opaque-2, Southwestern.

Estudos para a identificação de fatores de transcrição em raiz de reserva de mandioca: Fatores de transcrição desempenham importantes funções em vários processos fisiológicos. Nos últimos anos, muitos fatores de transcrição têm sido isolados de plantas, emergindo como poderosas ferramentas na manipulação de características agronômicas. No presente trabalho, iniciamos estudos para isolar fatores de transcrição de mandioca (Manihot esculenta Crantz), importante cultura tropical e subtropical. Nossos resultados revelaram três tipos de proteínas diferencialmente expressas na raiz de reserva de mandioca (Manihot esculenta Crantz):e imunologicamente relacionadas com o fator de transcrição opaco-2 de milho. Experimentos de Southwestern mostraram duas proteínas capazes de interagir in vitro com uma seqüência de DNA do gene be2S1 de castanha-do-brasil.

Palavras-chave: bZIP, elementos em cis-atuantes, expressão, regulação gênica, opaco-2, Southwestern.

Plant transcription factor studies have contributed substantially in the elucidation of gene expression mechanisms in several physiological processes, such as development of seeds (Schmidt et al., 1990; Yunes et al., 1994) and vascular tissues (Yin et al., 1997), ABA and light responses (Foster et al., 1994), plant defense and stress tolerance (Singh et al., 2002). Transcription factors are sequence-specific DNA-binding proteins that are capable of activating and/or repressing transcription. They are largely responsible for the selectivity of gene regulation and are often expressed in a tissue-specific, developmental-stage-specific, or stimulus-dependent manner. The utilization of transcription factors in the ma- nipulation of plant traits and in the regulation of transgene expression has been described (Martin, 1996; Ordiz et al., 2002; Segal et al., 2003).

A well described transcription factor of the bZIP class, essential for the expression of endosperm-specific storage protein genes, is opaque-2 (O2) from maize, involved in the regulation of expression of the b-32 albumin, pyruvate orthophosphate dikinase-1 and the 22- and 14-kDa zein gene families (Schmidt et al., 1990; Madalloni et al., 1996). The maize relatives coix and sorghum contain homologous $\mathrm{O} 2$ genes that regulate the expression of $\alpha$-coixin and $\alpha$-kafirin storage protein genes, respectively (Ottoboni et al., 1993; Vettore et al., 1998). 
We have found in the promoter of a brazil nut $2 \mathrm{~S}$ albumin gene (be $2 S 1)$ sequences related to cis-acting elements found in the $\alpha$-zein and $\alpha$-coixin promoters. These elements were located around an ACGT or ACCT core and were able to interact with maize O2 (Vincentz et al., 1997). This finding in particular led us to speculate whether the nucleotides coding for the rather conserved basic region of this factor might be of use in prospecting for potential components of regulatory networks in crops of socio-economical importance. For these investigations we chose cassava (Manihot esculenta Crantz) because nowadays cassava is one of the most important food crops in the tropics and is ranked in fourth place, after rice, maize and sugarcane with respect to furnished calories (Puonti-Kaerlas, 1998).

The cassava storage root results from the swelling of adventitious roots through secondary growth. According to anatomical studies initiated by Cabral et al. (2000), the cassava storage root contains five different tissue layers: L1composed of phellogen and phelloderm, L2-composed of phloem and vascular cambium, L3-composed of parenchyma cells at an early developmental stage, L4-composed of secondary xylem and developed parenchyma cells packed with starch granules and L5-composed of primary xylem and mature parenchyma cells. Studies on the isolation and characterization of cassava storage root protein genes were recently initiated by de Souza (2001). In these studies an $18 \mathrm{kDa}$ protein was identified with high similarity to the small heat-shock protein class, as well as an alcohol-soluble protein similar to allergenic Hev b5 from rubber-tree (de Souza, 2001; de Souza et al., 2002).

In the present work our aim was to identify in cassava potentially transactivating bZIP-like coding regions and proteins through genomic hybridization with homologous probes, immunological homologies and DNA-protein interaction experiments. Southern blot analysis showed that genomic sequences with homologies to maize $\mathrm{O} 2$ are present in the cassava genome. Strong hybridization signals, as intense as the signals obtained with maize DNA itself (figure 1, lane 1), were observed only with cassava DNA (lanes 10 and 11). Weak signals were observed in Brazil nut and taro DNA samples (lanes 4, 8 and 9).

Proteins reacting with antibodies raised against maize $\mathrm{O} 2$ and interacting with the DNA sequence of the be2S1 gene from the Brazil nut tree are expressed differentially in the tissue compartmentalization model of cassava storage root described by Cabral et al. (2000). Our results show that polyclonal antibodies raised against the bZIP domain of $\mathrm{O} 2$ recognized a protein of about $25 \mathrm{kDa}$ and detected only in layer 2 (composed of phloem and vascular cambium), while a $33 \mathrm{kDa}$ protein was present in all layers of cassava root (figure 2B). Antibodies against $\mathrm{O} 2$ also reacted with a 45 $\mathrm{kDa}$ protein detected in layers 2 and 4 (figure 2B). No reaction was seen with these proteins and the pre-immune serum (figure 2A).

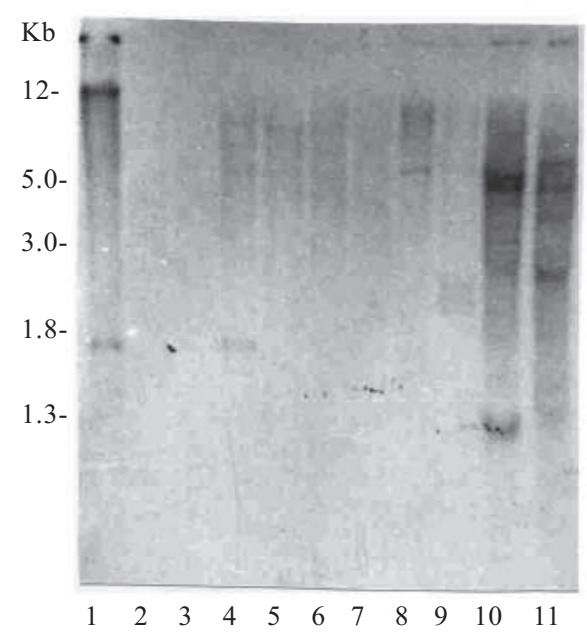

Figure 1. Identification of homologue sequences to the regulatory $\mathrm{O} 2$ gene from maize in the genome of various plant species by Southern blot analysis. Restricted DNA samples were separated on $0.8 \%$ agarose gel and probed with a radiolabeled probe from the basic region of $\mathrm{O} 2$ of maize. Lanes 1: Genomic DNA from maize digested with Hind III; 2 and 3: DNA samples from potato digested with EcoRI and Hind III, respectively; 4 and 5: DNA samples from Brazil nut digested with EcoRI and Hind III, respectively; 6 and 7: DNA samples from bean digested with EcoRI and Hind III, respectively; 8 and 9: DNA samples from taro digested with EcoRI and Hind III, respectively; 10 and 11: DNA samples from cassava digested with EcoRI and Hind III, respectively.

In the present work we used four DNA fragments (A-the $1.0 \mathrm{~kb}$ PstI/NcoI fragment from the $\alpha$-coixin gene promoter of coix, B-the 285 bp Sau $3 A I$ fragment from the PstI/NcoI from the $\alpha$-coixin gene promoter of coix; $\mathbf{C}$-the $1.4 \mathrm{~kb}$ and D- the 265 bp fragments EcoRI/HindIII/NcoI from the pTJ2 plasmid containing the be2S1 gene promoter of Brazil nut) containing cis-elements to $\mathrm{O} 2$ to test the in vitro DNA-protein interaction with cassava root proteins. Two fragments contain entire promoter sequences of $\alpha$-coixin (A) and almost entire promoter sequence of Be2S1 (C) genes, while the other fragments contain the specific cis-elements to opaque2. Fragment B (285 bp $\alpha$-coixin) contains the cis-element AGACATGTCAT described by Yunes et al. (1994). The DNA 
fragment with $265 \mathrm{bp}$ from Be2S1 gene (D) contains the F1 (TCCACGTCGA), F2 (GCCACCTCAT) and F3 (TCCACGTACT) elements described by Vincentz et al. (1997). Our results show that only fragment C, containing the almost entire promoter sequence from Be2S1 gene, was capable of interacting with proteins from cassava root (figure 3). Interestingly, the $45 \mathrm{kDa}$ protein immunologically related to opaque- 2 showed interaction with this fragment in samples from tissue layers 2, 3 and 4. A protein with molecular mass above $45 \mathrm{kDa}$ and present only in the tissue layer 3 also interacted with this element (figure $3 \mathrm{~A}$ ). No reaction was observed for proteins from leaves.
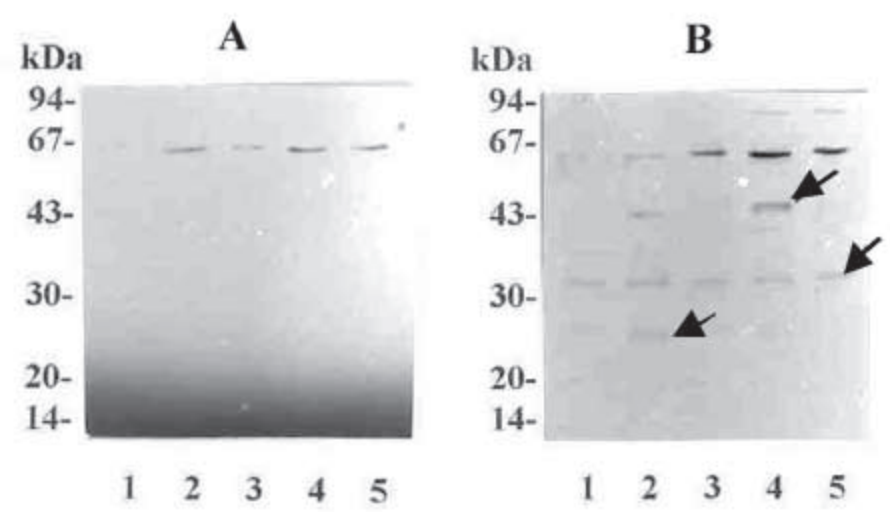

Figure 2. Identification of $\mathrm{O} 2$-like proteins in cassava storage root extracts by Western blot analysis. Samples containing $40 \mu \mathrm{g}$ of total protein were separated by SDS-PAGE, transferred to nitrocelulose membranes and probed with polyclonal antibodies raised against the $\mathrm{O} 2 \mathrm{bZIP}$ domain (B) and pre-imunne serum (A). Lanes: 1 to 5-crude extracts from cassava root layers L1 to L5, respectively. The arrows indicate the proteins recognized by anti-O2 antibodies.
A

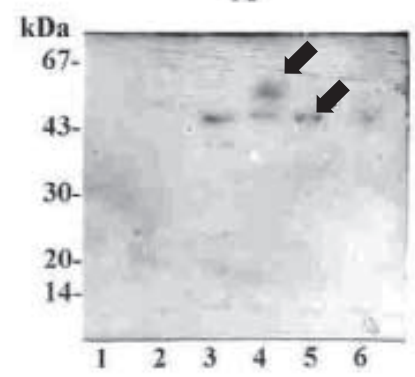

B

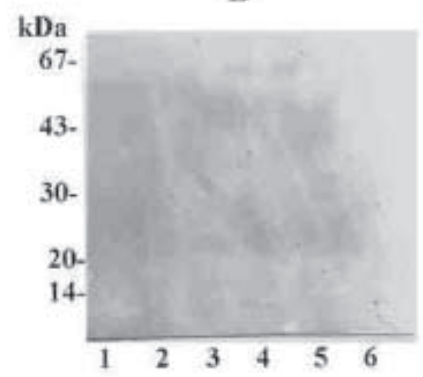

Figure 3. Southwestern analysis of cassava proteins with 1.4 $\mathrm{kb}$ promoter fragment of be $2 \mathrm{~S} 1$ gene from Brazil nut trees (A) and $1.0 \mathrm{~kb}$ promoter fragment from the $\alpha$-coixin gene (B). Lanes: 1- crude extract from leaves; 2 to 6- crude extract from storage root layers 1 to 5 , respectively. The arrow indicate the proteins interacting with the be2S1 promoter.
The prospecting for genes with socio-economically interesting features is a priority for genetic resources and biotechnology programs. Within this context we initiated a search for regulatory genes in an important tropical and subtropical crop, the cassava. $\mathrm{O} 2$ is a regulatory protein identified in three cereal species (maize, coix and sorghum) that regulates the gene expression in seeds. In the present work we attempted to test the hypothesis of the presence of $\mathrm{O} 2$ like proteins in cassava storage root. Our results show the presence of sequences homologous to the basic region of opaque- 2 from maize in the cassava genome. Since the basic region is a conserved domain among bZIP proteins, the maize opaque- 2 gene is more closely related to cassava than other species analyzed, under the experimental conditions used. Studies of homology at the antigenic relations level indicated the presence of potential bZIP regulatory proteins in cassava root proteins. Interestingly, the $45 \mathrm{kDa}$ protein immunologically is related to opaque-2 and also showed interaction with the DNA fragment from the Be2S1 gene promoter from Brazil nut. Since our results show no interaction between the DNA fragment (D) containing F1 and F2 cis-acting elements to opaque-2 from Be2S1 and this $45 \mathrm{kDa}$ protein (data not shown), it is probable that the interaction observed occurred despite the presence of others cis elements in this promoter sequence. The protein with molecular mass above $45 \mathrm{kDa}$ was not recognized by opaque- 2 antibodies (figure $2 \mathrm{~B}$ ), indicating that this protein detected only in parenchyma cells at early developmental stage (figure 3A) can belong to another transcription factor class. Future experiments will focus on the isolation of genomic sequences coding for these potential regulatory proteins and functional analysis.

Acknowledgments: CRBS was supported by a Doctoral fellowship from the Brazilian National Research Council (CNPq). This research was funded in part by EmbrapaCenargen and the Fundação de Apoio a Pesquisa do Distrito Federal (FAP-DF).

\section{REFERENCES}

Cabral GB, Carvalho LJCB, Schall BA (2000) The formation of storage root in cassava. In: Carvalho LJCB, Thro A.M., Vilarinhos AD (eds). Cassava Biotechnology. IVth International Scientific Meeting-CBN. EmbrapaRecursos Genéticos e Biotecnologia.Brasília-DF, Brazil. pp 345-356. 
de Souza CRB (2001) Isolamento e caracterização molecular de genes e proteínas de raiz de reserva de mandioca (Manihot esculenta Crantz). Brasília, Universidade de Brasília. PhD thesis.

de Souza CRB, Carvalho LJCB, de Almeida ERP, Gander ES (2002). Towards the identification of cassava storage root protein genes. Plant Foods Hum. Nutr. 57:353-363.

Foster R, IsawaT, Chua N-H (1994) Plant bZIP proteins gather at ACGT elements. FASEB J. 8:192-200.

Madalloni M, Domini G, Balconi C, Rizzi E, Gallusci P, Forlani F, Motto M (1996) The transcripitional activator opaque-2 controls the expression of a cytosolic form of pyruvate orthophosphate dikinase-1 in maize endosperms. Mol. Gen. Genet. 250:647-654.

Martin C (1996) Transcription factors and the manipulation of plant traits. Curr. Opin. Biotechnol. 7:130-138.

Ordiz MI, Barbas CF, Beachy R (2002) Regulation of transgene expression in plants with polydactyl zinc finger transcription factors. Proc. Natl. Acad. Sci. USA 99:13290-13295.

Ottoboni LMM, Leite A, Yunes JA, Targon PNML, Souza Filho GA, Arruda P (1993) Sequence analysis of 22kDalike alfa-coixin genes and their comparison with homologous zein and kafirin genes reveals highy conserved protein structure and regulatory elements. Plant Mol. Biol. 21-765-778.

Puonti-Kaerlas J (1998) Cassava Biotechnology. Biotechnol. and Gen. Engineer. Rev. 15: 329-364.
Schmidt RJ, Burr FA, Aukerman MJ, Burr B (1990) Maize regulatory gene opaque-2 encodes a protein with a "leucine-zipper" motif that binds to zein DNA. Proc. Natl. Acad. Sci. USA 46-50.

Segal DJ, Stege JT, Barbas CF (2003) Zinc Fingers and green thumb: manipulating gene expression in plants. Curr. Opin. Plant Biol. 6:163-168.

Singh K, Foley R, Onate-Sanches L (2002) Transcription factors in plant defense and stress responses. Curr. Opin. Plant Biol. 5:430.

Vettore AL, Yunes JA, Cord Neto G, Da Silva M, Arruda P, Leite A (1998) The molecular and functional characterization of an opaque-2 homologue gene from Coix and a new classification of plant bZIP proteins. Plant Mol. Biol. 36: 249-263.

Vincentz M, Leite A, Neshich G, Vriend G, Mattar C, Barros L, Weinberg D, de Almeida ER, Paes de Carvalho M, Aragão F, Gander ES (1997) ACGT and vicilin core sequences in a promoter domain required for seed-specific expression of a $2 \mathrm{~S}$ storage protein gene are recognized by the opaque- 2 regulatory protein. Plant Mol. Biol. 34:879-889.

Yin Y, Zhu Q, Dai S.; Lamb C, Beachy R (1997) RF2a, a bZIP transcriptional activator of the phloem-specific rice tungro baciliform virus promoter, functions in vascular development. EMBO J. 17: 5247-5259.

Yunes JA, Cord Neto G, da Silva MJ, Leite A, Ottoboni LM, Arruda P (1994) The transcriptional activator opaque-2 recognizes two different target sequences in the $22 \mathrm{kD}$ like a prolamin genes. Plant Cell 6:237-249. 